World Maritime University

The Maritime Commons: Digital Repository of the World Maritime University

\title{
Needs analysis of English for Specific Purposes (ESP) courses in vocational higher education
}

Nurmala Elmin Simbolon

Pontianak State Polytechnic

Follow this and additional works at: https://commons.wmu.se/imla2021

Part of the Education Commons

\section{Recommended Citation}

Simbolon, N. E. (2021). Needs analysis of English for Specific Purposes (ESP) courses in vocational higher education. In Pazaver, A., Manuel, M. E., Bolmsten, J., Kitada, M., Bartuseviciene, I. (Eds.), Proceedings of the International Maritime Lecturers' Association. Seas of transition: setting a course for the future (pp. 149-161). World Maritime University. http://dx.doi.org/10.21677/imla2021.16

This Paper is brought to you courtesy of Maritime Commons. Open Access items may be downloaded for noncommercial, fair use academic purposes. No items may be hosted on another server or web site without express written permission from the World Maritime University. For more information, please contact library@wmu.se. 


\title{
Needs Analysis of English for Specific Purposes (ESP) courses in vocational higher education
}

\author{
Nurmala Elmin Simbolon \\ Associate Professor, Department of Marine and Fisheries, Pontianak State Polytechnic, \\ Pontianak, Indonesia, simbolon73@gmail.com
}

\begin{abstract}
Due to the ratification of Standards of Training, Certification, and Watchkeeping for fishing vessel personnel 1995 (STCW-F 1995), Standard Marine Communication Phrases (SMCP) should be incorporated in the curriculum of the Maritime Education Training (MET) institutions for fishing vessel industries. This study examined the curriculum of a Maritime English course in vocational higher education in Indonesia. Data were extracted from the SMCP document, past Maritime English examination papers of Certificate of Competency, and the current syllabus of English for Specific Purposes (ESP) courses. Interviews with three seafarers who had work experience in fishing vessels were also conducted. The SMCP document was analyzed using NVivo 12 Plus software. The results showed that the examination lacked spoken language skills mainly required in the SMCP. According to the interview, there was a need for a review of the ESP curriculum to sufficiently equip graduates with English language skills in occupational and social settings within the workplace. Furthermore, there is a need to adopt a genre-based approach and include the digital-era-related skills for the review of the current ESP courses curriculum.
\end{abstract}

Keywords: Maritime English, ESP, genre-based approach, vocational higher education

\section{Introduction}

Since English is used as a lingua franca in regional institutions worldwide, its proficiency is vital for graduates from non-Anglophone countries. Indonesia is a member of the Association of Southeast Asian Nations (ASEAN) Economic Community (AEC). Therefore, its university graduates need to be proficient in using English to enrich their communication skills. The importance of English proficiency is emphasized in the definition of the regional community below.

A region that is fully integrated with the global economy, which includes a coherent approach to building external economic relations, such as Free Trade Area (FTA) negotiations, Comprehensive Economic Partnership (CEP), and increasing participation in global production and distribution networks (Nizar, 2014, p. 6)

The ASEAN Qualification Reference Framework (AQRF) states that the mobility of professionals should be developed (ASEAN, 2015). For this reason, university graduates may experience high competition in the global job market. This prediction is in line with the McKinsey Global Institute (MGI), which stated that in the next decade, the demand for semiskilled and skilled workers may triple (Handayani, 2015). This underscores the importance of English language skills for Indonesian job seekers globally. 
In 2017, the English Proficiency Index (EPI) ranked the Indonesian population $10^{\text {th }}$ in the Asian region (Renandya, Hamied \& Nurkamto, 2018). It was preceded by neighboring countries, such as Singapore, Malaysia, the Philippines, and Vietnam. Some factors, including approaches and curriculum used in English Language Teaching (ELT) programs, could be associated with this ranking. Inadequacy of English-speaking skills affects the competitiveness of Indonesian labor in the world. A survey by the Institute of Management Development (IMD) in 2012 in 59 countries revealed that Indonesia's labor productivity was relatively lower, occupying the second last position. A subsequent study conducted a few years later ranked Indonesia $50^{\text {th }}$ out of 142 countries, dropping 5 ranks from the previous year. It was outperformed by its neighboring counterparts, such as Malaysia and Thailand. (Schwab, 2015). The features of the millennial and post-millennial era reflect the skills demanded by industries globally. Some categories used to measure the competitiveness of the world's labor was based on the adoption of Information and Communication Technologies (ICT), skills, and labor market (Schwab, 2015). Since English is currently used as a lingua franca in many fields, Indonesian graduates should master it to gain a competitive advantage in the global market.

Since the ratification of the Standards of Training, Certification, and Watchkeeping for fishing vessel personnel 1995 (STCW-F 1995) by the Indonesian government in 2019, there has been an urgent need to improve the quality of Indonesian graduates. This is especially true for those in the Fishing Technology study program, where the current research was conducted. For example, one of the regulations in the STCW-F 1995 regarding the minimum requirement for the certification of seafarers in charge of a navigational watch on fishing vessels of 24 meters in length states that:

[The officers should have] adequate knowledge of the English language enabling the officers to use charts and other nautical publications, and to understand meteorological information, and messages concerning the ship's safety and operation. [They also should have] ability to understand and use the IMO Standard Marine Communication Phrases [SMCP] (Regulation 2 Article 17 of STCW-F 1995).

The SMCP is a document with a glossary of terms and oral expressions used by seafarers in maritime fields. To ensure the safety of ships and crew, the International Maritime Organization (IMO) developed this document using the standard navigation communication that is accepted across the world. It also provides some of the guidelines for the Maritime English course curriculum implemented by global MET institutions in one of its model courses: the IMO Model Course of Maritime English (IMC 3.17).

There are consequences for Maritime Education Training (MET) providers, including one Indonesian vocational university, that motivated this study. Including SMCP in the curriculum presents a challenge and an opportunity for the institution. Students enrolling for English as a Foreign Language (EFL) may encounter challenges because of limited Basic English skills. As a result, they may need extra effort to succeed in this program. On the other hand, the ratification of the STCW-F 1995 enables graduates to globally compete in the Marine and Fisheries sector. Hence, Maritime English is key to the success of graduates in the Marine and Fisheries labor market.

\subsection{English for Specific Purposes (ESP) and Genre-based Approach}

Maritime English is an approach in ELT that employs content knowledge and skills like those of Fishing Technology to guide language learning objectives (Hutchinson \& Waters, 1987). 
English for Specific Purposes, or ESP is often associated with a genre-based approach due to its precise discourse community, where members (seafarers) have a specific communication goal (Swales, 1990). Though the genre-based approach allows for guidelines to develop an ESP course curriculum, it is arguably limited and prescriptive (Freedman \& Meadway, 1994). To maintain safety and conformity to global recognition, the Maritime English course is characterized by fixed terminology and specific expressions. (Zhang \& Cole, 2018; Noble, 2017). To address this flaw, Dudley-Evans and St. John (1998) proposed an overarching approach that combines English for Academic Purposes (EAP) and English for Occupational Purposes (EOP), helping students improve their learning experience. EAP is known for providing learners with transferrable language skills, such as listening to lectures, note-taking, and discussions, widely used in their social setting. The introduction of the EOP to the Maritime English curriculum prepares learners for communication at the workplace.

\subsection{Studies on ESP Courses}

Several studies on ESP courses have been carried out. For example, Belyaeva (2015) conducted a needs analysis study at a university in Ukraine. The study focused on approaches used in developing the ESP course curriculum and recommended that EAP courses be introduced, followed by ESP. To help students learn their ESP, the survey suggested the incorporation of the four language skills on listening and note-taking. While Belyaeva based the findings on the students' experience, a similar study by Tran (2018) focused on the importance of the English language by police officers at their stations in Vietnam. The results showed that listening and speaking were the main skills needed in this field (Tran, 2018). Action-based research conducted by Morgan and Alfehaid (2019) in Saudi Arabia's university supports the recommendations of Belyeva's study. By placing ESP in tandem with GE, the study showed that GE helped students learn ESP. This underscores the need for students to devote more time to learning and practicing GE (Morgan \& Alfehaid, 2019). Therefore, this research emphasizes the need to examine in detail how the phrases in SMCP should be presented in the ESP course curriculum. It also explains how the incorporation of GE or EAP could be implemented in the ELT curriculum.

Some studies on Maritime English courses have been conducted (Zhang \& Cole, 2018; Noble, 2017). Zhang and Cole (2018) examined the curriculum revision of the IMO Model Course of Maritime English (IMC 3.17). They focused on the ability of an ESP-based framework to connect Maritime English to a communicative language teaching approach. This revision process involved conducting workshop questionnaires and interviewing stakeholders from the Maritime field. Apart from seafarers' listening and speaking skills, in emergencies, crosscultural understanding was also highlighted by Zhang and Cole (2018). Their proposal divided the Maritime English syllabus into two, including General Maritime English (GME) and Specific Maritime English (SME). Like EAP, GME focuses on pronunciation and listening, and speaking as the language's core activities. SME encourages professionals with maritimerelated skills to focus on English learning. The latter category refers to what Dudley-Evans and St. John (1998) would categorize as EOP. This proposal seems to be comparable with the incorporation of GE and ESP courses in Belyeva (2015) and Morgan and Alfehaid's (2019) studies. Since it provides two aspects of communication skills, it can enable the graduates to improve their performance at work.

For students to communicate efficiently in English in their workplace, Zhang and Cole's (2018) study suggested a variety of learning approaches. Chambers and Main (2016) examined the use of tools for learning and teaching in a Maritime English course. In particular, they utilized a 
simulator in the course and tested its benefits. Testing 21 ship captains' performance under poor weather conditions and mechanical issues, the results indicated that simulator-based training was effective (Chambers \& Main, 2016). The simulation-based curriculum study stresses the importance of including digital training methods (Schwab, 2015) in an ESP course. From a different aspect, Noble (2017) examined the need for global standard English testing for seafarers around the world. By examining the Maritime English test provided by 'Marlins' and 'Seagull', the study showed that they lacked international recognition for excluding crosscultural aspects, proposed in Zhang and Cole's (2018) study. This article also discusses the method and content of the assessment of the Maritime English course.

In Indonesia, few studies have examined the effectiveness of Maritime English teaching in MET institutions. With informally discussing the institution instructors, some voiced the problem of limited English proficiency among cadets. However, there is limited documentation of this particular concern, with Ownie (2010) and Dirgayasa (2014) being the only available studies. In 2018, Dirgayasa investigated what MET students need and established that apart from SMCP and the specific terminologies, listening and speaking skills were important in learning English. This finding stressed why speaking proficiency is valuable for Fishing Technology graduates. It aimed to establish whether the current curriculum of ESP courses met the learning requirements. In this research, the essential communication skills by Indonesian seafarers are analyzed in relation to the ratification of the STCW-F 1995 by the state. The intention is to shed light on the arrangement of ESP courses and give recommendations on directions to be taken by Indonesian vocational universities including MET. To enhance the competitiveness of fishing vessel personnel in light of these objectives, the research questions focus on:

1. Communication skills required for a seafarer according to the SMCP document

2. Language skills assessed in the Maritime English examination

3. The ESP courses syllabus structure in vocational higher education

4. Indonesian seafarers' attitude on the use of the English language when working in the fishing vessel industry

\section{Research Methods}

This study was conducted at the Advance University in Indonesia using a mixed-methods approach for data triangulation (Creswell \& Plano Clark, 2011). To answer the research questions, interview notes, the SMCP, past Maritime English examination papers in a Certificate of Competency, and the syllabus of the Maritime English course were examined.

\subsection{Research Context}

Fishing Technology is a three-year study program at Advance University, where students are required to take an examination to obtain a Certificate of Competency for fishing vessel personnel. To apply for a job in any Indonesian fishing vessel company, the seafarers should produce this certificate and comply with the STCWF-1995, articulated in Regulation 2 Article 17, English proficiency. The certification examination is designed to assess the student on several courses, such as Maritime English, Radar Navigation, Oceanography, Communication (at sea), and International Regulations for Preventing Collisions at Sea, (COLREGs). This makes the Maritime English examination the guideline for the Maritime English syllabus. The study program offers this course in its first three semesters with different approaches. In

Semester 1, GE is taught while the subsequent two semesters introduce ESP courses relating 
to the Marine and Fisheries field. Apart from the program's incapability to enhance learners' English proficiency, it does not set minimum English skill is required for enrolment.

\subsection{Data Collection and Analysis}

Data was collected by examining the SMCP, the past Maritime English examination papers of the Certificate of Competency, and the curriculum of the English course at the study program. Furthermore, interviews were also conducted with the respondents. The analysis of SMCP was essential to examine whether the standards required by IMO in the STCW-F 1995 have been met.

The analytical methods used were determined by the data collected. NVivo 12 Plus software was employed to organize, analyze, and capture some details from the data of the SMCP document. The analysis of the past examination papers was conducted quantitatively using the Excel program. These examination papers, the syllabus, and interviews were analyzed using iterative content analysis for uniformity in the results (Krippendorff, 2004). The validation of interpretation was conducted in the initial stage of data analysis. Two content lecturers at the faculty were invited to examine the relevance of ideas and topics captured from the data. For instance, the use of 'general terms' in the topic elicited from the question items of the Maritime English examination was clarified and was important in differentiating between general and specific terms in Marine and Fisheries field. To authenticate the interview notes, there was follow-up communication with the participants. By incorporating triangulation data using 3 types of documents and 3 unstructured interviews with the seafarers, the reliability of this research was maintained.

\subsection{Research Participants}

Purposive sampling was used in selecting participants (Creswell \& Plano Clark, 2011). A participant was required to have worked as a seafarer on-board a fishing vessel. Two participants were current University staff while the third one was their former colleague working at a different institution. Before the interviews were done, the participants were informed about the purposes of the research, and their consent was provided in informal communication. The unstructured interviews were conducted by phone and some follow-up communication was arranged through social media. Table 1 summarises the profile of each participant's work experience on-board a fishing vessel.

Table 1 .

The Profile of The Faculty Members

\begin{tabular}{|l|l|l|l|}
\hline $\begin{array}{l}\text { Name } \\
\text { (pseudonyms) }\end{array}$ & $\begin{array}{l}\text { Length of work at a } \\
\text { fishing vessel }\end{array}$ & $\begin{array}{l}\text { Types of the } \\
\text { fishing vessel }\end{array}$ & $\begin{array}{l}\text { The language used } \\
\text { in the vessel }\end{array}$ \\
\hline Barus & 1 year & Long Line & $\begin{array}{l}\text { Indonesian with } \\
\text { limited English }\end{array}$ \\
\hline Ikang & Less than 2 years & Long Line & Japanese \\
\hline Budi & 5 years & Long Line & Indonesian \\
\hline
\end{tabular}

\subsection{Research Procedures}

The research was conducted in 2019 after the Indonesian Ministry of Higher Education and Research Technology (now RISTEK-BRIN) approved the research proposal. Data collection involved two steps: document collection and conducting interviews. The data comprised 
information from the SMCP, current syllabi of English courses, and Maritime English examination past papers (between the year 2012 to 2017). The interviews were then conducted with three faculty members in the Indonesian language by the researcher. In translating direct quotes from the interview, the article employs a non-verbatim English translation.

\section{Results}

\subsection{RQ1: Which Communication Skills are Required for A Seafarer According to the SMCP Document?}

The findings showed that oral communication is the main language skill required by the seafarers. The following figures from the analysis of the SMCP document using the NVivo software. Figures 1 and 2 show the top ten of the most frequently mentioned words in the SMCP document.

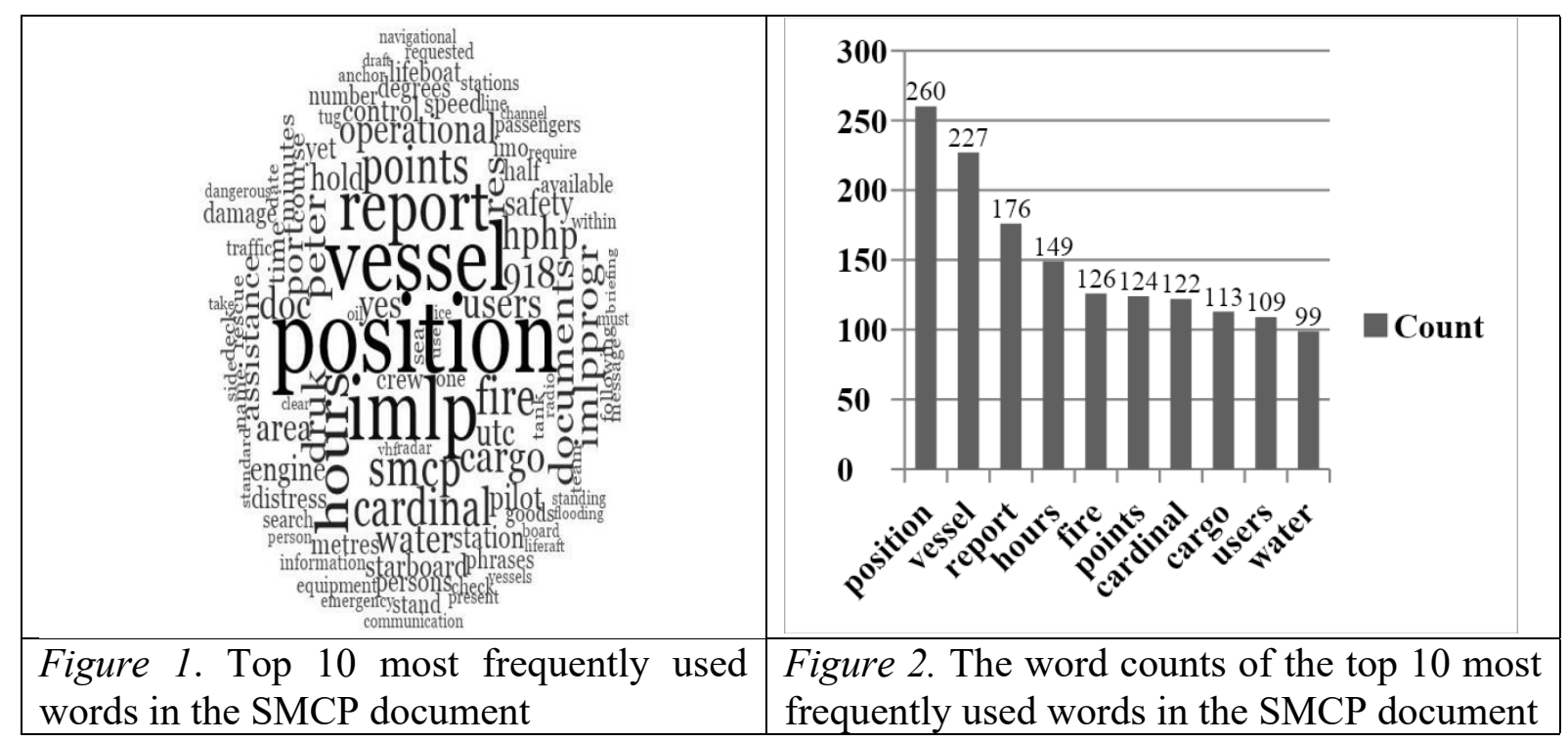

Maritime communication features eight types of messages including instruction, question answers, and information. The following extracts taken from different pages (in brackets) of the document exemplify the commonly used phrases in oral communication.

"Do not overtake the vessel North of you" (13)

"I will not overtake the vessel North of me." (13)

"Are dangerous goods on fire?" (29)

"Yes, dangerous goods are on fire" (29)

"My ETA at distress position within ... hours / at ... UTC" (33)

The oral expressions indicate the specific features of prescriptive English for Occupational Purposes (EOP), showing that learning should emphasize specific and fixed patterns in Maritime English. This is exemplified by the instruction message on page 13 and questions on page 29 that necessitates specific patterns of responses. Moreover, the message on page 33 shows the time and needs to be expressed using the Universal Time Coordinated (UTC) method in separate digits. For instance, when the time is $15.50 \mathrm{UTC}$, it should be expressed as one five five zero-hours local time. Since seafarers from a diverse linguistic background might express time in a way affected by their first language, the UTC system was meant to mitigate this 
problem. These findings suggest a specific prescription of communication at sea, which has become the specialty of ESP in the vocation at sea.

\subsection{RQ2: Which Language Skills are Assessed in the Maritime English Examination?}

The results from the analysis of this research question suggest there is a weak correlation between the examination, the document, and the SMCP. Table 2 shows the structure of the examination, the coverage of the topics, and some samples of the examination items.

Table 2.

The Items of Maritime English Examination Questions (Years 2012-2017)

\begin{tabular}{llll}
\hline Forms & Number of items & Topics & \\
\hline Multiple choice & 20 & See Figures 1 and 2 & \\
Reading comprehension & 1 & Ship Building & \\
English-Indonesian sentence & 5 & Fisheries, & Collision \\
translation & & Regulations & \\
\hline
\end{tabular}

As indicated in Table 2, the examination tested the reading and comprehension skills of the language because they are frequently used on Marine and Fisheries issues. Figure 3 shows the range of vocabulary included in the examination.

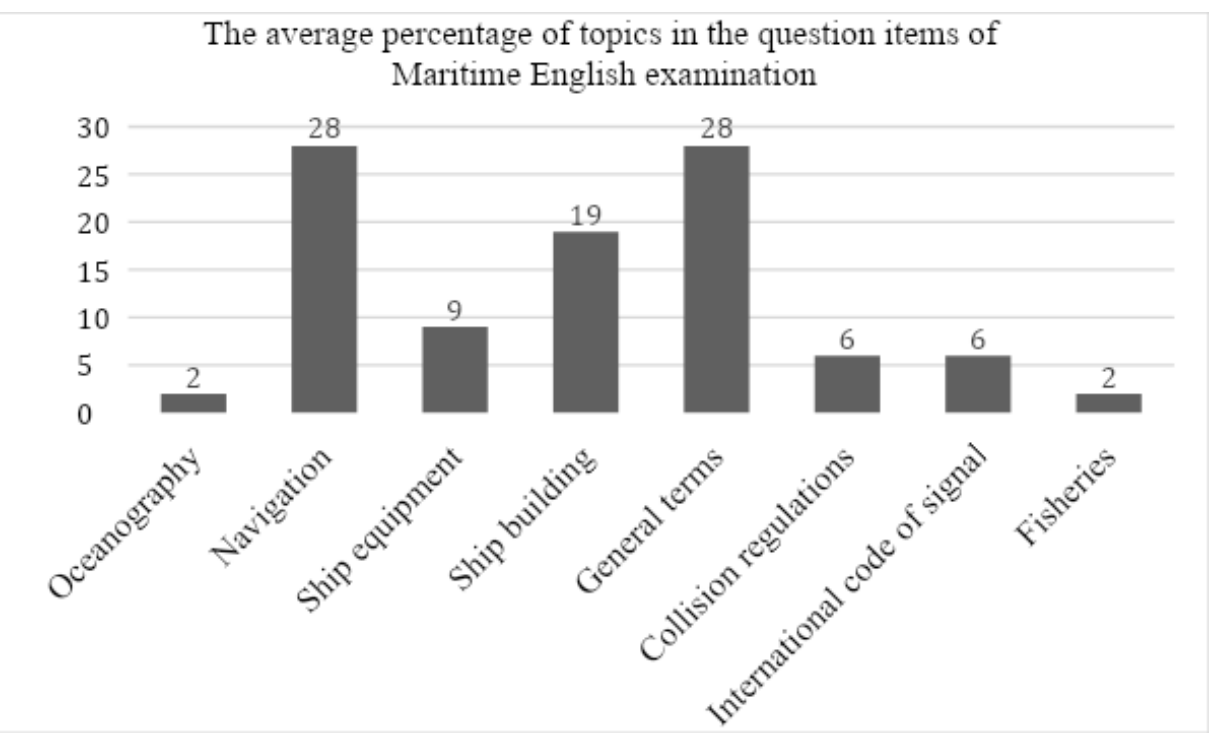

Figure 3. The average percentage of the number of topics in Maritime English examination questions.

Figure 3 shows that the topics of the examination cover terminologies related to different courses offered in the program. Several items relate to the topics of 'Navigation' and 'General terms.' Consequently, some key points can be grasped from the content presentation of the assessment. The first category 'General terms' comprises common vocabulary, which is important in supporting the learner's' foreign language learning process. This practice singularly assesses reading and comprehension skills. The current Maritime English examination only assesses basic language skills of the cadets' reading ability on vocabulary and comprehension. This passive language skill is relevant when dealing with manuals or written instruction. According to the findings, the current understanding of the assessment value of Maritime English skills in the global industries might be limited. Instead of using international standards, they consider the Certificate of Competency used by the local industries only. This 
is shown by the interviews with the seafarers, presented in Section 3.4. The limited scope of this ESP assessment could also be attributed to the absence of STCW-F 1995 ratification by the government.

Another flaw identified from the analysis of past examination papers is that examination on oral expressions used in the fishing vessels was done in a written form. This makes it difficult to test the cadets' English-speaking proficiency. A few sample examination questions can be found in Appendix 1.

The current assessment of English proficiency of the seafarer through the Maritime English examination emphasizes the mastery of technical terminology in Marine and Fisheries field but fails to assess spoken English language skills. Therefore, this examination lacks the assessment of listening and speaking skills that are required by seafarers in the world.

\subsection{RQ3: What is the Structure of ESP Syllabus Courses in Vocational Higher Education?}

The results of the research question meet the requirements specified by the global organization of Maritime English. However, a closer examination reveals a lack of specific details to support its implementation in the classroom. The details of the syllabus of the ESP courses for the institution are shown in Appendix 2.

The language syllabus is divided into two GE for Semester 1 and ESP for Semesters 2 and 3. English 1, offered in Semester 1, accommodates Basic English speaking skills, while English 2 done in Semester 2 employs presentation of a procedural text. Its objective focuses mostly on the field of Marine English using one-way communication. In semester 2, there is an intensive mastery of the technical vocabulary of the program. Semester 3's syllabus is designed to prepare students to face the Certificate of Competency examination with emphasis on accommodating the curriculum recommended by the IMO. The topics covered in each lesson follow the SMCP document with a limited assessment of oral skills in the Maritime English examination as shown on RQ2. This confirms that spoken English language skills are considered less important in classroom learning.

\subsection{RQ4: The Indonesian seafarers' attitude on the use of the English language in the fishing vessel industry?}

Two main questions were asked in the interview, including how the English language was used in their workplace, and how the crew communicated to individuals that spoke the different first language in the fishing vessels. Their responses varied greatly, as summarized in Table 3. 
Table 3.

Seafarers' Perspectives on the Language Used When Working in a Fishing Vessel

\begin{tabular}{|l|l|l|l|}
\hline $\begin{array}{l}\text { Participant's Name (The } \\
\text { Nationality of Fishing Vessel } \\
\text { Owner) }\end{array}$ & $\begin{array}{l}\text { Ikang } \\
\text { (Japanese) }\end{array}$ & $\begin{array}{l}\text { Budi } \\
\text { (Indonesian }\end{array}$ & $\begin{array}{l}\text { Barus } \\
\text { (Australian) }\end{array}$ \\
\hline 1. Use of General English & No & No & $\begin{array}{l}\text { Yes } \\
\text { (interpreter) }\end{array}$ \\
\hline $\begin{array}{l}\text { 2. Use of Maritime-related } \\
\text { terminology/phrases (SMCP) }\end{array}$ & $\begin{array}{l}\text { No } \\
\text { (The radio } \\
\text { operator only) }\end{array}$ & Yes & $\begin{array}{l}\text { Yes } \\
\text { (interpreter) }\end{array}$ \\
\hline $\begin{array}{c}\text { 3. Use of English in social } \\
\text { interaction among the crew }\end{array}$ & No & No & No \\
\hline
\end{tabular}

Based on these findings, the following can be deduced. First, although working on fishing vessels from different nationalities, all seafarers interviewed had limited social interaction using the English.

Second, all interviewees did not use English in their social interactions among the crew. Despite being the same, these responses have different implications. For example, Ikang, working on a Japanese vessel, had good Japanese skills and maintained social communication with fellow seafarers in Japanese. Budi's often used the Indonesian language for two reasons. First, the owner of the fishing vessel company that Budi worked for was Indonesian. Consequently, there was no need to use a foreign language in informal situations. Also, fellow seafarers mostly from Korea used Indonesian instead of English. The responses expressed a willingness to practice English as he expressed in this way "I could not express it in English, as he [Budi's co-worker] had limited English, so I used the Indonesian language. He had already learned some Indonesian when applying for the position at the vessel" (Budi, Personal communication, 24 August 2019). A similar sentiment was also articulated by another seafarerparticipant. The crew saw the need for a common language for all seafarers to help them socially interact at sea. This proposition is supported by the other seafarer-participant. Barus shared the experience in the following

We often have an interpreter provided by the company to helps us during fishing. However, when I wanted to talk with my colleagues during the off-duty time, I felt reluctant to ask for the interpreter's help. I always used body language when communicating with the other crew fellow at the vessel. (Barus, Personal communication, 25 August 2019).

The interviews also established that Maritime-related oral expressions presented in the SMCP document were used by everyone, except one person. According to Ikang, "It is the Fishing Master, who communicates with the radio communication officer and the crew on the fishing ship" (Ikang, Personal communication, 20 August 2019). When Ikang mentioned the two types of communication, each context used a different language. The officer in charge of radio communication used English when communicating with the Master of the vessel, who utilized the Japanese to communicate with the crew, including the participant of this study. Although the first language choice is in line with the requirement of the STCW-F 1995, the other one seems to be dictated by the context of the industry. Ikang stated that "In the vessel where I worked, the crew did not need to master phrases in the SMCP, except for the radio communication officer." (Ikang, Personal communication, 20 August 2019). 


\section{Discussion}

\subsection{Limited GE Means Limited ESP}

Some key issues stand out from the findings of this study. First, the language skills assessed in the Maritime English examination and the research context do not fully address the needs of global industries. Although the examination focuses mostly on reading, as part of the receptive skills of the language, the job market needs specific vocabulary in the Marine and Fisheries sector. Spoken communication that involves the speaking skills of the language is imperative. Vocabulary learning is key in developing reading skills, a component of the language tested at the Maritime English Certificate of Competency examination. It is argued that the assessment strategy should be used in occupational-related texts encompassing vocabulary and grammar. For example, the assessment including the use of these terminologies is a sentence dialogue between the officer and the captain instead of asking the definition of each term. This improves the learners' English language communication skills, hence enhancing their labor competitiveness. The argument proposes a need for the examination to include assessments on listening and speaking skills. Oral expression examination should be tested in speaking form. This helps students practice actual speaking. According to Dirgayasa (2018) and Zhang and Cole (2018), lack of a comprehensive assessment of the English skills leads to limited listening and speaking skills. This finding was in line with the findings of Noble's (2017) study that proposed the need for further evaluation of current English assessment for the seafarers to meet global standards. This means the current assessment in the ESP course examination for the seafarers of fishing vessels does not satisfy the need for world industries.

The study also recommends that the current arrangement of ESP courses in the institution be reviewed for various reasons. First, seafarers need to practice English language skills to exploit future relevant opportunities. Upon improving the current method of assessment in Maritime English, this problem will be addressed. Second, setting procedural texts within the course syllabus is not useful since the cadets mostly require listening and speaking on specific types of messages. Third, the curriculum offers students insufficient time and content in learning GE. This affects the learners' capability to master the language. Unlike the setting in Morgan and Alfehaid's (2019) study, these learners did not have an English background before the study. One-semester for the GE course is insufficient to support ESP learning. Fourth, the implementation of EAP where transferrable language skills, such as listening and note-taking are taught, should be included in the GE course (Dudley-Evans \& St. John (1998). Therefore, this study suggests that the GE course be reviewed to cater to the students' learning needs and equip them for learning ESP (Belyaeva, 2015; Hutchinson \& Waters, 1987; Morgan \& Alfehaid, 2019). The finding may reflect the experience of some seafarers in Indonesia, including Budi and Barus.

Lack of reliable features of the current local regulations may be attributed to limitations of the ESP courses curriculum and the lack of comprehensiveness of the English language assessment. This study incorporated the findings from the examination papers before the STCWF-1995 had been ratified. English, being a lingua franca, egged the comprehensive assessment of its proficiency among the global citizens. All these findings explain the low English proficiency of Indonesian graduates worldwide (Renandya et al, 2018). According to this study, it is prudent to immediately rearrange the language's curriculum in vocational higher education in Indonesia to meet the needs of the global market. The following section shows the potential rearrangement that can be made. 


\subsection{Genre-based Approach for An ESP Course Development}

Adopting a genre-based approach for ELT courses, which comprises ESP, would help accomplish certain learning objectives. The seafarers' community has a specific discourse (Swales, 1990) with types of communication purposes at the sea. The communication is meant to give responses to the messages heard, such as 'question' and 'instruction'. For this reason, the syllabus should be redirected by adopting the genre-based approach. For example, in the Maritime English course in Semester 3, it is not advantageous to present the subtopics as 'Terminologies 1' and 2' to the students'. These could be substituted with a topic 'Types of Messages' to guide the whole syllabus and improve the oral language skills relevant to the industry and students' needs (Tran, 2018; Hutchinson \& Waters, 1987). Employing the use of a set of simulators would provide learners with a similar context to their future work setting (Chambers \& Main, 2016). Furthermore, the use of simulators is necessary where learners have to match the features of the digital era (Schwab, 2015). The study shows that a genre-based approach can be implemented even in the GE course. Similar to Morgan and Alfehaid (2019) and Belyaeva's (2015) studies, this study advises stakeholders to adopt the EAP approach for students to enhance their communication skills. The academic settings provide a generic discourse for the students to practice the language skills. For example, note-taking activities and discussions are likely to support the graduates' listening and speaking skills. Additionally, these skills are valuable in the broader context of social life, including their social interaction with colleagues (Dudley-Evans \& St. John, 1998).

It is vital to include competence in cross-cultural understanding in the language assessment platform and ESP course design (Zhang \& Cole, 2018). This is because many crews work in a diverse environment with seafarers from various backgrounds and different languages and cultures. Adopting a genre-based approach into the ESP course design would make it easy to relate the learning goals to the needs of a specific discourse community. Therefore, the graduates would be equipped with communication skills for both occupational and social purposes.

\section{Conclusions}

This study examined the current curriculum of the ESP courses in a vocational university by analyzing specific communication skills needed by seafarers at fishing vessels in Indonesia. The data were extracted from documents (the SMCP, past paper of examination, and English course syllabi) and interviews with relevant participants in the Maritime industry. The results showed that the current Maritime English course examination is ill-equipped in preparing students for the requirements of the global standards for seafarers. Moreover, the ELT course curriculum can be reviewed to gain the needed cross-cultural knowledge. This requires the adoption of a genre-based approach for English language courses. This should include the ESP (Maritime English) for students to comprehensively learn the language. Helping university graduates grow their English proficiency through comprehensive language learning enhance work skills and communication between individuals with different backgrounds. The ability to communicate in this lingua franca help improve work performance, gaining a competitive edge in the labor market.

Making a broader application of the findings on this subject is a challenge since the research was limited to only one institution. Concerning the generic features of a language, the adoption of a genre-based approach in ESP courses could apply to a similar discourse practice. 


\section{Acknowledgements}

I would like to thank the Ministry of Higher Education and Research Technology (Now called RISTEK-BRIN) which has provided the funding enabling this researcher to conduct the above research.

\section{References}

Association of Southeast Asian Nations (ASEAN). (2015). Asean qualifications reference framework. https://asean.org/asean-economic-community/sectoral-bodies-under-the-purviewof-aem/services/asean-qualifications-reference-framework/

Belyaeva, A. (2015). English for Specific Purposes: Characteristic features and curriculum planning steps. Sustainable Multilingualism, 7, 73-91.

Chambers, T., \& Main, R. (2016). The use of high-fidelity simulators for training maritime pilots. Journal of Ocean Technology, 11(1), 118-131.

Creswell, J. W., \& Plano Clark, V. L. (2011). Designing and conducting mixed method research (2nd ed.). Thousand Oaks, CA: Sage.

Dirgayasa, I., W. (2014). Survey of English teaching and learning process in Maritime Education and Training in Indonesia: A case study in private MET in Indonesia. English Language Teaching, 7(7), 111-119. doi: 10.5539/elt.v7n7p111.

Dirgayasa, I., W. (2018). The need analysis of Maritime English learning materials for nautical students of Maritime Academy in Indonesia based on STCW '2010 curriculum. English Language Teaching, 11(9), 41-47. doi: 10.5539/elt.v11n9p41.

Dudley-Evans, T., \& St. John, A., M. (1998). Developments in English for Specific Purposes: A multi-disciplinary approach. Cambridge: Cambridge University Press.

Freedman, A. \& Meadway, P. (1994). Do as I Say: The Relationship between Teaching and Learning New Genres. In A. Freedman \& P. Medway (Eds.), Genre and the New Rhetoric (pp.191-210). London: Taylor\& Francis. Freedman.

Handayani, T. (2015). Relevansi lulusan perguruan tinggi di Indonesia dengan kebutuhan tenaga kerja di era global [The relevance of the graduates of Indonesian universities to the needs of the wokplace in the globalisation era]. Jurnal Kependudukan Indonesia, 10(1), 53-64. doi:10.14203/jki.v10i1.57.

Hutchinson, T., \& Waters, A. (1987). English for Specific Purposes: A learning centred approach. Cambridge: Cambridge University Press.

Krippendorff, K. (2004). An introduction to its methodologies (2nd ed.). Thousand Oaks, CA: Sage Publications, Inc.

Morgan, G., \& Alfehaid, A. (2019). The evaluation of an English for Specific Purposes course taught to pre-sessional undergraduate students in tandem with General English. The Asian ESP Journal. 15(3), 56-98. 
Nizar, M., A. (2014). Laporan dampak ASEAN Economic Community terhadap sector industri dan jasa, serta tenaga kerja di Indonesia [Report on theimpact of ASEAN Economic Community on industrial, service sectors and the workforce in Indonesia].

Noble, A. (2017). Maritime English put to the test! The feasibility and desirability of setting global standards for Maritime English: A survey based study. University Press Antwerp.

Ownie, S., J. (2010). Pengembangan modul ESP - Bahasa Inggris Maritim berorientasi kebutuhan pasar untuk mahasiswa Jurusan Nautika pada Akademi Maritim di Indonesia [The development of ESP modules - market-needs-oriented Maritime English for the students of Nautical Program in the Academy of Maritime in Indonesia]. In D. Widayati, T. T. Zein, Sumarsih, Mahriyuni, T. Syarfina, Marice, Nurlela, \& Gustianingsih (Eds.), Language, Literature and Culture in Southeast Asia: Malay and Indonesian studies. Graduate School of Linguistics Universitas Sumatera Utara.

Renandya, W., A., Hamid, F. A., \& Nurkamto, J. (2018). English language proficiency in Indonesia: Issues and prospects. The Journal of Asia TEFL, 15(3), 618-629.

Schwab, K. (2015). The Global Competitiveness Report.

Swales, J.M. (1990). Genre analysis: English in academic and research Settings. Cambridge: Cambridge University Press.

Tran, T., T., H. (2018). English language needs in listening and speaking skill of police officers in Vietnam: Basis for ESP syllabus design. The Asian ESP Journal, 14(7.2), 251-279.

Zhang, Y., \& Cole, C. (2018). Maritime English as a code-tailored ESP: Genre-based curriculum development as a way out. Iberica, 35, 145-170. 